\title{
Tropes and Trench Cakes: The Home Front in the Media and Community History
}

The extensive investment of money, time and resources dedicated to the commemoration of the centenary of WWI has offered possibilities for writing multiple__istories and interpretations of the conflict, and re-imagining and positioning the place of the home front within histories of the war. If, as Tosh suggests: 'the rationale of public history is to maximize the presence of history in the public sphere, ${ }^{\prime i}$ then the first year of the WW1 centenary has been successful and led to a variety of outputs from media texts to community projects, including over $140 \mathrm{WWI}$ related programmes commissioned by the BBC." The WW1 'fest' of recent months has ranged from collaborative endeavours between academics and media, or local communities and artists, drama and dance professionals, to activities which construct the public as a passive recipients of historians, curators, scriptwriters or journalists' views of the pastiii and maybe many more which see academic history as irrelevant.

Projects have included: the Women in Theatre group's exploration of women workers at the Birmingham Small Arms Factory ${ }^{\text {iv; }}$; the Clapham Film Unit and the UK Section of the Women's International League for Peace and Freedom (WILPF) looking at the women who tried to stop the war in 1915, ${ }^{\vee}$ whilst Haslemere Museum and Girl Guiding, Liphook together researched the effect of the conflict on their locality ${ }^{\mathrm{vi}}$. Family historians, heritage or local history groups and enthusiastic users of Ancestry.com or digitized local and national newspapers archives, popular reproductions of WWI cookbooks, diaries and memoirs also traced their ancestors, baked trench cakes and set up websites. Poppies and war memorials may still dominate in WWI commemoration but in the media and community groups the home front is becoming more visible. Homes and housewives, food and families, farms and the factories, refugees and migrant workers, children and charity are now part of national cultural memories of the Great War. Those with a commitment to Women's or Community histories, produced as well as consumed beyond the academy, have welcomed this phenomenon. However alongside the thrust to make the history of the conflict more inclusive, to democratize 
knowledge production, there are questions to be asked about whether it is possible to inject this outpouring of public history with the critical edge that John Tosh and Ludmilla Jordinova suggest 'counters the cozy assumptions of public memory and raises more questions than it answers' ${ }^{\text {vii }}$

Media and community histories of WWI are inevitably consumed, and sometimes produced, as leisure activities; they are part of what Dorothy Sheridan has referred to as the 'war industries,', ${ }^{\text {vii }}$ used by commercially-orientated and fiercely competitive contemporary heritage and media institutions to boost their audience figures or visitor numbers for museum exhibitions, tourist attractions, television and radio programmes. Furthermore, the current climate of austerity and consequent cuts in funding for archives, museums, libraries, arts and the BBC has led many individuals and organisations to participate in the WWI centenary; for many archives and museums, funding bids to Heritage Lottery Fund $(H L F)^{i x}$ or the Arts Council ${ }^{x}$ and institutional engagement with the conflict is framed by the need to prevent redundancies and to justify their roles and relevance. There is a consequent impetus on curators, education officers, screenwriters and producers to turn a war that involved industrial-scale killing and maiming of millions of people into a palatable form of entertainment, often by privileging a focus on the home front.

For those in the heritage sector, navigating a tortuous terrain between the competing pulls of entertainment and education, inclusivity and accuracy, parochialism and contextualization, democratizing knowledge production and ensuring academic rigor, the home front is perhaps seen to offer scope to broaden the groups of people who will engage with the conflict. Every individual heritage project or media text is shaped by the institutional, economic and political motivations of both organisations and individuals; their organizational priorities, budgets, time scales, and professional practices frame history they produce. Tight budgets, limited time frames and a heavy reliance on part-time volunteers can lead to a dependency on quick and readily identifiable signifiers 
of the conflict: familiar tropes and myths invested with meaning and symbolism which are part of a national narrative of the 'Great War' as a significant point of change. The home front is portrayed by munitionettes, VADs and land girls who are all repeatedly reproduced as part of the popular trope that war liberated and enfranchised women. That academic historians may challenge this narrative is irrelevant when sources for other women's lives on the home front are sparse, and digital resources and popular reproductions of propaganda posters can be used to support such popular myths.

Those who produce public history in the BBC, museums and the heritage sector, like community groups, do not share academics' assumed hierarchies of knowledge, nor necessarily, their questioning scepticism towards many sources. Local, family, community and national memories and histories, in which many may have a high personal investment, compete with academic research. Ideally historians can work with communities and the heritage sector by adopting a strategy of questioning, chipping away at, stretching and occasionally challenging popular and oft repeated tropes whilst working to contextualise local histories. Yet such work is but a drop in the ocean of the plethora of popular representations of WW1. Historians have to recognise and reconcile themselves to the existence of multiple forms of knowledge about the past, and to the excitement and possibilities of the histories that lie beyond the academy. Histories which recount how Will Haynes of Pershore, Worcestershire was sent home from France during the Battle of the Somme to help his wife and family gather in the fruit harvest, ${ }^{x i}$ or of Mary Jowett, with five small children and two sons at the front who was fined for stealing bacon and eggs from a local butcher the previous year ${ }^{\mathrm{xi}}$ are being brought to light by the work of family and community historians ${ }^{\text {xii }}$

Much more problematic is how historians can respond to individuals and groups who have a strong investment in a narrative which is not merely aberrant or 'mythical', but rather factually wrong. What is the appropriate response to a village exhibition, which tells of the trauma of a mother whose son 
was 'conscripted' into the army in 1915 aged $16 .{ }^{\text {xiv }}$ An emphasis on academic rigour would suggest the need to point out that conscription was not introduced until 1916, and that perhaps he volunteered. Whilst the challenges of reconciling competing narratives of the past are not a new phenomenon to historians of the twentieth century ${ }^{\mathrm{xv}}$; the national profile of histories of WWI suggests such selectivity may have political nuances. Focusing on families and highlighting the domestic consequences of armed conflict potentially engages the general public; Hilda Kean has suggested that ordinary people value 'the past as a way of answering questions about their own identity, immortality, and responsibility'. ${ }^{\text {xvi }}$ However, the example above suggests that such familycentred histories can be problematic; one understanding of the factual inaccuracy of this lad's 'conscription' is that it serves to construct both mother and son as victims. Maybe it an inadvertent narrative strategy which makes the horrors of war more palatable; it avoids many difficult questions about the complicity of ordinary people in the killing and violence. Indeed as Joanna Bourke has pointed out, the war dead are now increasingly remembered as partners, children and parents rather than as soldiers with guns. ${ }^{\text {xvii }}$

Alternatively, the BBC, which has placed itself at the forefront of the WWI Centenary commemoration, in part in response to the institution's need to legitimate its public service remit and validate the corporations very existence, seeks to prioritise factual accuracy. It does however inevitably construct the past according to its particular institutional norms, values and cultural priorities that may seem alien to many historians. Multiple radio and television programmes produced over recent months have subjected WW1 to what John Ellis describes as contemporary broadcasting culture's tendency 'to work through' issues, until it 'exhausts an area of concern, smothering it in explanations from almost every anglexviii. This has led to an acknowledgment that there are multiple histories of the conflict: regional, military, social, scientific, technological, cultural, women's and black histories; it has not predictably given all of these prime-time viewing slots. The lexicon of narratives 
and images of WWI constructed through the BBC programming produced in the first year of the WWI commemorations have however given significant space to domestic, personal and intimate life on the home front. Even in a political thriller such as 37 Days (BBC 2014), which dramatized the political manoeuvring between the shooting of the Archduke Ferdinand and the outbreak of WWI, much of the action took place in sitting rooms or soirees of Prime Minister Asquith's family or focused on the personal relationships of political players.

This is inevitable for broadcasting as it is a domestic medium; from its earliest days an awareness that its audiences were in the intimate, domestic sphere of the home shaped the focus and tone of programming. In the 1920s, as radio shifted from an 'unruly guest to a friend in the corner, ${ }^{\text {'xix }}$ it adopted an intimate mode of address which placed the broadcaster at the listener's fireside. It developed a tone, linguistic style and focus appropriate for the home and gave precedence to personal and family concerns, which led to a 'domestication' of the airwaves. ${ }^{x x}$ In the ensuing years, television and radio's domestic consumption, its often feminine concern with private and personal stories of individuals, continued to structure this mode of communication. These then are the cultural norms and expectations which still shape the BBC histories of WWI, and ensure the home front has a significant place. Broadcasting Histories are also framed by their genre, channel and scheduling slot, and by the consequent budgets and time scales which govern their production. Great War Diaries (BBC 2014) was an international co-production by 25 broadcasters that interwove material from the journals and diaries of 14 individuals to tell multiple histories from both sides of the conflict. It both avoided parochialism and in drawing attending to the patriotic war fervour of all sides in the conflict, it offered a critique of such sentiments and drew attention to the contradictions and inherent horror of a war which wrecked so many people's lives. Similarly, BBC's Radio 4's drama series Home Front, scheduled to run intermittently over the full four years of the commemoration, with a cast of over 30 characters and three geographical settings, portrays multiple experiences of war. Both these texts, 
commendably emphasise that no one particular history of the conflict encompasses the history of the war. ${ }^{x \times i}$ The opening scenes of Home Front portray a young girl in Folkestone whose pregnancy and plans to marry a German waiter are thwarted by the outbreak of war, immediately drawing attention to the effects of war on ordinary people. As it develops it includes the seamier sides of the conflict, featuring characters that are self-interested skivers, profiteers, charlatans or busybodies. These, however, are national and international productions, intended to have some longevity as DVDs or downloadable podcasts. They operate with a more generous budget and timescale than most media texts, and are very much produced for the general public, not by them.

BBC audiences had a greater input into the 1400 stories produced by eleven BBC regions and three BBC Nations, which made up the World War One at Home project ${ }^{x x i i}$ which was a result of a collaboration between local journalists and Arts and Humanities Research Council funded academics. ${ }^{x x i i i}$ Viewers, listeners, local museums and archives also contributed memories and memorabilia for many of the stories. Some were both entertaining and educational, stretching listeners' perception of the effects of how the conflict shaped the lives of women on the home front. These included the narrative of Margaret Francis, a mother from Herefordshire who, a week after giving birth, left her village and children to travel to France to visit her eldest son who had been accidentally gassed by the British, and the story of the women of Much Wenlock in Shropshire, who collected eggs to be sent to wounded soldiers. The collaboration between academics and the BBC illuminated the differences in the professional cultures of universities and broadcasters. There were clashing perceptions of research, knowledge, time management and what constituted a good story; as Louise Brieley who led the project in the West Midlands pointed out: 'academics wanted fine detail and context, journalists wanted a story that grabbed the attention of the audience and good talkers'. ${ }^{\text {xiv }}$ Nevertheless World War One at Home included uncomfortable histories of the conflict, such as the Minnie Pit mining disaster at Halmer End in Staffordshire in which 144 died, 48 of whom 
were young lads under the age of 17. This history did not provide the familiar tropes of the WWI home front; it was rather an uncomfortable history, which raised questions about poverty and capitalism, exploitation and abuse and the unpalatable nature of the British society that was being fought for. As the WWI-fest rolls on, academics have to continue to find ways to engage in numerous ways with media and community groups' multiple histories of the home front - and continue to nudge them towards the contemplation of more uncomfortable pasts and critical questions.

\footnotetext{
'Tosh, J. 'Public History, Civic Engagement and the Historical Profession in Britain History' History: The Journal of the Historical Association, 2014 pp192- 212 p192.

ii For further details see http://www.bbc.co.uk/programmes/p01nb93y

iii See Kean, H. Martin, P. and Morgan, S. (eds), Seeing History: Public History in Britain (London, 2000); Ludmilla Jordanova, History in Practice (London, 2000), ch. 6, Winter, J. M. 'Public history and historical scholarship', History Workshop Journal, 42 (1996), pp. 169-70; de Groot, J. Consuming History: Historians and Heritage in Contemporary Popular Culture (London, 2009).

iv Women in Theatre Group Ahttp://womenandtheatre.tumblr.com ccessed 27 January 2016.

${ }^{\vee}$ East London Suffragettes site http://eastlondonsuffragettes.tumblr.com Accessed 27 January 2016.

${ }^{v i}$ https://www.historypin.org/channels/view/51823\#! photos/list/

vii Madge Dresser, M. 'Politics, Populism, and Professionalism: Reflections on the Role of the Academic Historian in the Production of Public History' The Public Historian, Vol. 32, No. 3, pp. 39-63, p 40, Tosh, J. Why History Matters (Basingstoke, Hampshire: Palgrave Macmillan, 2008), 99-119; Jordanova, J. History in Practice, 2nd ed. (London: Hodder Arnold, 2006), 126-31.

viii Sheridan D. Unpublished Paper presented at National Memorial Arboretum 16 February 2012.

${ }^{\text {ix }}$ A number of small community groups have, gained funded from the Heritage Lottery Funds First World War : then and now scheme https://www.hlf.org.uk/looking-funding/our-grant-programmes/first-world-war-thenand-now Accessed 27 January 2016.

${ }^{x}$ Grants for the Arts has supported dance, visual arts and theatre projects http://www.artscouncil.org.uk/funding/grants-arts/ Accessed 27 January 2016.
}

${ }^{x i}$ Will Haynes letters in the private collection of Nancy Fletcher, Pinvin Worcestershire.

xii Worcester Herald, July 101915.

xiii These are both narratives uncovered through community group and student research for Andrews, M. and Waugh, J. ( eds. ) How the Pershore Plum Won the Great War (Stroud, 2016). 
xiv This example comes from an exhibition at a HLF funded project in the West Midlands, specific village name withheld.

xv See for example Summerfield, P. Reconstructing women's wartime lives: Discourse and Subjectivity in Oral Histories of the Second World War (Manchester 1998) or Andrews, M 'Narrative Tropes and Emotional Realism in Memories of Evacuees to Staffordshire' in Children In War:' The International Journal of the Evacuee and War Child Studies Vol 1 No 10 pp. 57-62.2013.

${ }^{x v i}$ Kean, H. 'People, Historians, and Public History: Demystifying the Process of History Making' The Public Historian, Vol. 32, No. 3, pp. 25-38, p27.

xvii Bourke, J. Wounding the World (London, 2014) p1.

xviii Ellis, J. Seeing Things (London 2000) pp. 79-80.

xix Moores, S. "'The box on the dresser". Memoirs of early radio and everyday life.' Media Culture and Society, 198810(1): 23-40.

${ }^{x x}$ Andrews, M. Domesticating the Airwaves: Broadcasting, Domesticity and Femininity (London, 2012).

${ }^{x \times i}$ For further details see BBC WWI http://www.bbc.co.uk/programmes/b047qhc2 Accessed 27 January 2016.

xxii BBC WWI World War One at Home http://www.bbc.co.uk/programmes/p01nhwgx accessed 27 January 2016.

xxiii Arts and Humanities Research Council.

http://www.ahrc.ac.uk/research/fundedthemesandprogrammes/worldwaroneanditslegacy/worldwaroneathom e/ Accessed 27 January 2016.

xxiv Louise Briely talk at the BBC, London, June 2014. 